\title{
Krabbe Disease: Report of a Rare Lipid Storage and Neurodegenerative Disorder
}

\author{
Pratyusha Pavuluri ${ }^{1}$, Sabitha Vadakedath ${ }^{2}$, Rajkumar Gundu ${ }^{1}$, Sushmitha Uppulety ${ }^{1}$, \\ Venkataramana Kandi ${ }^{3}$ \\ 1. Biochemistry, Chalmeda Anandrao Institute of Medical Sciences 2. Biochemistry, Prathima Institute of \\ Medical Sciences, Karimnagar, IND 3. Microbiology, Prathima Institute of Medical Sciences, Karimnagar, \\ IND
}

$\square$ Corresponding author: Venkataramana Kandi, ramana20021@gmail.com Disclosures can be found in Additional Information at the end of the article

\section{Abstract}

Krabbe disease is a rare (one in 100,000 births) autosomal recessive condition, usually noticed among children. It causes sphingolipidosis (dysfunctional metabolism of sphingolipids) and leads to fatal degenerative changes affecting the myelin sheath of the nervous system. We report a case of a six-year-old male child who presented with symptoms of muscle spasticity and irritability. Diagnosis of this disease can only be made with clinical suspicion. Laboratory diagnosis includes brain magnetic resonance imaging (MRI), magnetic resonance (MR) spectroscopy, biochemical analysis of cerebrospinal fluid, and genetic analysis for detecting mutation in genes coding for galactosyl cerebroside (GALC). We report a case of late infantile Krabbe disease.

Categories: Neurology, Pediatrics

Keywords: krabbe disease, autosomal recessive sphingolipidosis, progressive neurologic degeneration, galactosyl cerebroside, globoid cell leukodystrophy

\section{Introduction}

Krabbe disease or globoid cell leukodystrophy is a rare (one in 100,000 births), autosomal recessive, neurodegenerative disorder affecting the myelin sheath of the nervous system. It is a lipid storage disorder responsible for sphingolipidosis (dysfunctional metabolism of sphingolipids) usually noticed among children. Krabbe disease is characterized by defective functioning of lysosomal enzyme $\beta$-galactocerebrosidase ( $\beta$-GALC) [1-2]. This enzyme is located on chromosome 14 and is responsible for accumulation of galactosyl ceramide. This produces a toxic compound psychosine, which damages white matter of the peripheral and central nervous system [3-4]. Based on the age of onset there are four forms of Krabbe disease, infantile, late infantile (very often parents ignore early signs), juvenile, and adult form [5-6]. Juvenile and adult forms are categorized as late onset Krabbe disease. The clinical classification of Krabbe disease is shown in Table 1. 


\section{Cureus}

\begin{tabular}{|c|c|c|c|}
\hline $\begin{array}{l}\text { Clinical } \\
\text { forms of } \\
\text { Krabbe } \\
\text { disease }\end{array}$ & $\begin{array}{l}\text { Radiological features } \\
\text { and other biochemical } \\
\text { parameters }\end{array}$ & Presenting symptoms & Morbidity/mortality \\
\hline $\begin{array}{l}\text { Infantile form } \\
\text { (Diagnosed at } \\
\text { first six } \\
\text { months of life) }\end{array}$ & $\begin{array}{l}\text { Brain MRI shows central } \\
\text { demyelination with } \\
\text { evidence of white matter } \\
\text { disease and optic atrophy. } \\
\text { CSF analysis shows raised } \\
\text { protein levels. }\end{array}$ & $\begin{array}{l}\text { Feeding difficulties, irritability, spasticity, hypertonia, } \\
\text { hyperesthesia, blindness, deafness, peripheral } \\
\text { demyelination causes progressive decline in } \\
\text { psychomotor activity, limb weakness, ataxia, and } \\
\text { seizures. }\end{array}$ & $\begin{array}{l}\text { Death within few } \\
\text { years of onset of the } \\
\text { disease. }\end{array}$ \\
\hline $\begin{array}{l}\text { Late infantile } \\
\text { form } \\
\text { (Diagnosed } \\
\text { between six } \\
\text { months to } \\
\text { three years of } \\
\text { life) }\end{array}$ & $\begin{array}{l}\text { Brain MRI shows high- } \\
\text { intensity areas of } \\
\text { demyelination in the } \\
\text { brainstem and cerebellum. } \\
\text { CSF analysis shows raised } \\
\text { protein levels. }\end{array}$ & $\begin{array}{l}\text { Normal early development is followed by } \\
\text { paresthesias, decreased muscle strength, spasticity, } \\
\text { ataxia, paresis, psychomotor arrest, psychomotor } \\
\text { deterioration, optic atrophy, visual loss, macular } \\
\text { cherry red spots, diminished head circumference, } \\
\text { macrocephaly, and seizures. }\end{array}$ & $\begin{array}{l}\text { Death within few } \\
\text { years of onset of the } \\
\text { disease. }\end{array}$ \\
\hline $\begin{array}{l}\text { Juvenile form } \\
\text { (Diagnosed } \\
\text { between } 2 \text { to } \\
10 \text { years of } \\
\text { age) }\end{array}$ & $\begin{array}{l}\text { Brain MRI normal in earlier } \\
\text { stages and CSF analysis is } \\
\text { usually normal. }\end{array}$ & $\begin{array}{l}\text { Early normal development is followed by rapid } \\
\text { psychomotor dysfunction, slower and progressive } \\
\text { nerve degeneration, irritability, spasticity, ataxia. } \\
\text { Seizures may be present. }\end{array}$ & $\begin{array}{l}\text { Longer life with mild } \\
\text { symptoms. }\end{array}$ \\
\hline $\begin{array}{l}\text { Adult form } \\
\text { (Diagnosed } \\
\text { after } 10 \text { years } \\
\text { of age) }\end{array}$ & $\begin{array}{l}\text { Brain MRI shows normal } \\
\text { features in early stages } \\
\text { and CSF analysis is } \\
\text { usually normal. }\end{array}$ & $\begin{array}{l}\text { Peripheral neuropathy, cerebellar dysfunction, } \\
\text { impaired higher cortical functioning, irritability, } \\
\text { spasticity, ataxia, seizures are present. }\end{array}$ & $\begin{array}{l}\text { Significantly long } \\
\text { life. }\end{array}$ \\
\hline
\end{tabular}

\section{TABLE 1: Clinical forms of Krabbe disease}

MRI - Magnetic resonance imaging. CSF - Cerebrospinal fluid.

We present a case of late infantile type of Krabbe disease. The CAIMS Institutional Ethical Board approved this study and the approval number is IEC/CAIMS/2016-1113. Informed consent was obtained from the patient's family for this study.

\section{Case Presentation}

A six-year-old boy presented with symptoms that included shock-like jerky movements of the limbs, inability to hold his neck, functional urinary incontinence, and dependence on the mother for most daily activities. There was no visual deficit, with normal ophthalmoscopic examination. A physical examination revealed hypertonicity and hyperreflexes in both upper and lower limbs with a positive Babinski sign. He was unable to speak but otherwise appeared to have normal intellectual ability. The family history reveals a third degree consanguineous parents with a history of Krabbe disease. The other child of the same parent was observed to be normal. Initially, the patient's mother found a defective suckling of milk at birth, which was compensated by bottle feed and weaning. The milestones were normal until the age of 
two when the patient developed fever associated with seizures. This episode of seizure was misdiagnosed as a common febrile seizure. After this episode there was progressive spastic tetraparesis that made him unable to walk, talk, and caused difficulty in swallowing. The patient was reported to suffer from approximately twenty episodes of seizures a day. He had great difficulty in swallowing and had to be fed only a semi-solid and liquid diet.

A brain magnetic resonance imaging (MRI) showed demyelination in the brain stem and cerebellum. A brain magnetic resonance (MR) spectroscopy revealed elevated myo-inositol and choline-containing compounds with decreased $\mathrm{N}$-aspartyl aspartate in the affected white matter area, and the grey matter showed neuronal degeneration. Mutational analysis by deoxyribonucleic acid (DNA) sequencing revealed a missense mutation on chromosome band 14q31.3, coding for GALC gene confirming Krabbe disease. The patient was advised to undergo physiotherapy to help maintain muscle tone and circulation. Cerebrospinal fluid evaluation, electroencephalography (EEG), and electromyography (EMG) tests could not be performed due to patient's concerns.

The patient was prescibed anticonvulsant drugs to minimize the seizure episodes and drugs to ease muscle spasticity.

\section{Discussion}

Krabbe disease occurs due to the deficiency of lysosomal enzyme galactocerebrosidase (expressed in oligodendrocytes and Schwann cells), which results in accumulation of a cytotoxic metabolite, psychosine (deacylated product of galactosylceramide). The accumulation of psychosine disrupts downstream biochemical pathways inhibiting activities of protein kinase $\mathrm{C}$ (PKC), mitogen-activated protein kinase (MAPK), dysregulates peroxisomal functions (inhibits plasmalogen synthesis required for myelin formation), activates caspases (apoptotic machinery), and thus, causes apoptosis of myelin-forming cells resulting in demyelination [78]. The pathway depicting dysfunctional GALC activity [2] is shown in Figure 1. 


\author{
Defect in Galactocerebrosidase \\ (present in oligodendrites, Schwann cells)
}

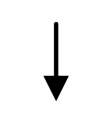

Accumulation of Galactoceramide

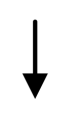

Deacylation of galactoceramide forms Psychosine

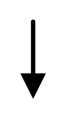

Inhibits Protein kinase-C (PKC)

Inhibits mitogen activated protein kinase but up regulates-

Jnk (a member of MAPK family) signal pathway

Activates sPLA2-IIA2 (a inflammatory sPLA2)

Activates Peroxisomal proliferator activator receptor alpha (PPAR-a)

Dysregulated peroxisomal function

Activated microglial / macrophage expression, caspases function

Myelin degradation

Formation of globoid cells (hall mark feature of Krabbe disease)

FIGURE 1: The pathway depicting consequences of mutation at chromosome 14 
disease [9].

Krabbe disease in infants is fatal due to decline in psychomotor activity, and death occurs before two years. Late onset (juvenile and adult forms) disease has slow progression and the patient has a significantly longer life. The difference in severity of progression and age of onset of the disease is due to the difference in the mutational area of this gene and also turnover of the psychosine [9-10]. The majority of mutations in late onset disease occur at 5'-end whereas the severe infantile form is due to mutation occurring at 3'-end [10].

Krabbe disease needs to be differentially diagnosed with other neurodegenerative disorders including GM2 gangliosidoses (lysosomal lipid storage disorders caused by mutations in at least one of three recessive genes: HEXA, HEXB, and GM2A), Gaucher disease (a rare genetic disorder characterized by the deposition of glucocerebroside in cells of the macrophagemonocyte system, resulting in the deficiency of enzyme glucocerebrosidase), metachromatic leukodystrophy (progressive, inherited, and neurodegenerative disorders), and sphingomyelinase deficiency (Niemann-Pick disease (NPD) is a lipid storage disorder that results from the deficiency of enzyme, acid sphingomyelinase). X-linked adrenoleukodystrophy (X-ALD) (common among children between four and eight years, resulting in elevated plasma concentration of very-long-chain fatty acids (VLCFA)); Pelizaeus-Merzbacher disease (PMD) (affects the cortical white matter); and Alexander disease (affects the cortical white matter) should also be considered for differential diagnosis.

Although hematopoietic stem cell transplantation (HSCT) is seen as a potential treatment for Krabbe disease, previous research has observed that there is a varying degree of benefit with HSCT. Significant benefit of HSCT was noted in patients who were asymptomatic or mildly symptomatic and when transplanted within the first month of life, signifying the importance of diagnosis as early as possible after birth. Other treatment modalities being tried to treat Krabbe disease include enzyme replacement therapy, targeting inflammatory markers, gene therapy, and neural stem cell transplantation. Considering the fact that the patient was already showing neurological manifestations including quadriplegia, he was closely monitored and necessary medical care was provided.

\section{Conclusions}

The present case highlights the importance of careful consideration of Krabbe disease among children with defective feeding habits. Although a feeding problem was noticed early in childhood in this case, it was ignored until the age of two years. Parents may be carriers of the gene responsible for Krabbe disease with no clinical symptoms, and clinical disease can be noted among children born to such parents. If suspected and diagnosed at the right time, stem cells from umbilical cord or bone marrow transplantation from an unrelated donor before onset of the symptoms may help in delaying neurological manifestations. The stem cells (embryonic) are unique because of their potential to develop into any type of cells and their ability to renew themselves. The use of stem cells in therapy is still in the phase of clinical trials, and much work has to be done before using it in the treatment. In conclusion, counselling families about the risk of disease and recommending prenatal testing in future pregnancies could help early diagnosis of Krabbe disease. To reduce the mortality and morbidity, necessary care by a neurologist, ophthalmologist, occupational therapist, audiologist, and physiotherapist is recommended.

\section{Additional Information Disclosures}

Human subjects: Consent was obtained by all participants in this study. Institutional Ethical 
Board issued approval IEC/CAIMS/2016-1113. Yes. Conflicts of interest: In compliance with the ICMJE uniform disclosure form, all authors declare the following: Payment/services info: All authors have declared that no financial support was received from any organization for the submitted work. Financial relationships: All authors have declared that they have no financial relationships at present or within the previous three years with any organizations that might have an interest in the submitted work. Other relationships: All authors have declared that there are no other relationships or activities that could appear to have influenced the submitted work.

\section{References}

1. Vargiami E, Papathanasiou E, Batzios S, et al.: Neuroradiological, neurophysiological and molecular findings in infantile Krabbe disease: two case reports. Balkan J Med Genet. 2016, 19:85-90. 10.1515/bjmg-2016-0011

2. White AB, Givogri MI, Lopez-Rosas A, Cao H, van Breemen R, Thinakaran G, Bongarzone ER: Psychosine accumulates in membrane microdomains in the brain of Krabbe patients, disrupting the raft architecture. J Neurosci. 2009, 29:6068-77.

3. Sakai N, Inui K, Fujii N, Fukushima H, Nishimoto J, Yanagihara I, Isegawa Y, Iwamatsu A, Okada S: Krabbe disease: isolation and characterisation of a full-length cDNA for human galactocerebrosidase. Biochem Biophys Res Commun. 1994, 198:485-91.

10.1006/bbrc.1994.1071

4. Fu L, Inui K, Nishigaki T, et al.: Molecular heterogeneity of Krabbe disease. J Inherit Metab Dis. 1999, 22:155-162. 10.1023/A:1005449919660

5. Thomas PK, Halpern JP, King RH, Patrick D: Galactosylceramide lipidosis: novel presentation as a slowly progressive spinocerebellar degeneration. Ann Neurol. 1984, 16:618-20. 10.1002/ana.410160515

6. Loonen MC, Van Diggelen OP, Janse HC, Kleijer WJ, Arts WF: Late-onset globoid cell leukodystrophy (Krabbe's disease). Clinical and genetic delineation of two forms and their relation to the early-infantile form. Neuropediatrics. 1985, 16:137-42. 10.1055/s-20081052558

7. Nagara H, Ogawa H, Sato Y, Kobayashi T, Suzuki K: The twitcher mouse: degeneration of oligodendrocytes in vitro. Brain Res. 1986, 391:79-84.

8. Tanaka K, Nagara H, Kobayashi T, Goto I: The twitcher mouse: accumulation of galactosylsphingosine and pathology of the sciatic nerve. Brain Res. 1988, 454:340-346.

9. Suzuki K, Taniike M: Murine model of genetic demyelinating disease: the twitcher mouse . Microsc Res Tech. 1995, 32:204-14. 10.1002/jemt.1070320304

10. Rafi MA, Luzi P, Chen YQ, Wenger DA: A large deletion together with a point mutation in the GALC gene is a common mutant allele in patients with infantile Krabbe disease. Hum Mol Genet. 1995, 4:1285-9. 10.1093/hmg/4.8.1285 